Final article:

Lindgreen, A. (2003), "Trust as a valuable strategic variable in relationship marketing: different types of trust and their implementation", British Food Journal, Vol. 105, No. 6, pp. 310-328. (ISSN 0007-070X)

For full article, please contact LindgreenA@ @ardiff.ac.uk

\title{
Trust as a Valuable Strategic Variable in the Food Industry:
}

\author{
Different Types of Trust and Their Implementation
}

\author{
Adam Lindgreen, Université catholique de Louvain, Belgium ${ }^{1,2}$
}

Key words Danish-British bacon supply chain; Qualitative multiple case study; Relationship marketing; Strategic variable; Trust; Types of trust

Word count: 5,684 (excluding references)

\footnotetext{
${ }^{1}$ Correspondence should be addressed to Adam Lindgreen, Unité Marketing, Institut d'Administration et Gestion, Université catholique de Louvain, 1 Place des Doyens, 1348 Louvain-la-Neuve, Belgium. Email lindgreen@mark.ucl.ac.be. Telephone + 32 - 1047 8481. Fax + 32 - 10478324.

${ }^{2}$ Warm thanks to the organisations that participated in this research. Equal thanks to Professor Kjeld Porsdal Poulsen for facilitating the fieldwork associated with the research. Thanks to Dr Arnold Boon, Mr Lasse Hinke and $\mathrm{Mr}$ Per Eidnes Sørensen for valuable suggestions during the initial stages of the study. Also thanks to my colleagues with Cranfield University and the University of Auckland for good advice. Finally, thanks many times to the two reviewers' very useful suggestions that helped improve my article.
} 


\title{
Trust as a Valuable Strategic Variable in the Food Industry: Different Types of Trust and Their Implementation
}

\begin{abstract}
Although it is often suggested that trust is an important construct in relationship marketing, there is only little empirical evidence of how, if at all, trust may be used as a valuable strategic variable. In the 1990s, the international food industry faced a number of serious challenges, most notoriously the mad cow disease. The present multiple case study, which is qualitative in nature, explores how the Danish-British bacon supply chain has dealt with the challenges by means of implementing different types of trust. The study confirms that there are different types of trust that marketers can embrace and shows that when one type of trust is not available marketers can draw on other types. The case study also maps different patterns of implementing trust-based marketing approaches.
\end{abstract}

\section{INTRODUCTION}

In an article on the need for developing a long-term approach to marketing in services marketing, Berry (1983) first coined the term relationship marketing. Although relationship marketing since then has received widespread attention, there is still no consensus as to what it constitutes (e.g., Harker 1999; Snehota and Söderlund 1998). The reason is, it has been suggested, that theoreticians have different vantage points and stress different applications of relationship marketing (Möller and Halinen-Kaila 1998). Indeed, Collins (1999) has argued that the history of relationship marketing is characterised by more rhetoric than publication 
effort on empirical evidence. In an effort to develop the theory of relationship marketing from empirical findings, a research study was, therefore, established.

The article is structured as follows. First, some of the challenges that the food industry faced in the 1990s are discussed; the Danish-British bacon supply chain in particular experienced a number of serious challenges. Moving on, the reader is first introduced to relationship marketing and the important construct of trust before areas where more empirical work needs to be carried out are identified. Following that, the results of a multiple case study - designed to investigate how marketers may use trust as a valuable strategic variable - are reported; the study is quality in nature. The case study was conducted in the Danish-British bacon supply chain in which the relationships between suppliers, processors and retailers on the one hand and consumers on the other hand were being studied. The research methodology is then described in some detail. The article concludes with a discussion of the findings and draws a number of theoretical and managerial implications as well as suggests directions for future research.

\section{THE CHALLENGES}

In the 1990s, the food industry faced a number of serious challenges. One case in point is the British government that caused widespread panic when, in March 1996, it announced that mad cow disease, or bovine spongiform encephalophathies (BSE), most likely had killed ten people (The Economist 1998a). Since then, more than forty people are reported to have died from the new-variant Creutzfeldt-Jakob disease, which is the human brain disease resulting from exposure to BSE (Murray 1999). With the British government paying some one and a half billion British pounds for cattle to be destroyed in 1997, the mad cow disease is the single 
most expensive catastrophe to have befallen British agriculture. Of special interest for this article is that it has been suggested that incompetence and secrecy in the British Ministry of Agriculture, Fisheries and Food have surrounded BSE with examples of British officials refusing to help outside researchers or, indeed, hiding information (The Economist 1998a, 1998b). Another case in point is the many incidents of bacterially contaminated meat, such as contamination of Camphylobacter, Escherichia coli, Listeria monocytogenes and $\underline{\text { Salmonella }}$ (Licking and Carey 1999; Tansey and Worsley 1995).

The incidents suggest that open communication between industry and government agencies is important; for example, effective, forthright notification of parties affected by a recall is a key consideration (Dulen 1999). Because of that, some companies have established crisis management teams that handle the product recall, send out notice to consumers and nominate a specific individual as media spokesperson (American Agent \& Broker 1999; Berry 1998).

The European food industry in particular was hit by a series of food scandals. For example, large quantities of oxblood were found in French wines; it was revealed that fruit and vegetables from Belgium, Spain and the Netherlands were being sprayed with antibiotics; and high levels of dioxins were discovered in Belgian food products (Morgenavisen JyllandsPosten 1998; Politiken 1999a; The Economist 1999a). In these episodes the concerned companies failed to inform the public appropriately and the respective governments did not notify the European Commission and the health authorities (Goddard 1999; Politiken 1999b).

It appears that only few food companies have installed procedures of advertising, informing and labelling (Buus 1999; The Economist 1999b). Not surprisingly, perhaps, many European consumers do not believe in the food industry or in the governments who are perceived as 
lying about food safety or withholding scientific data (Ratzan 1998). The overall result has been that there is little trust between the consumers on the one hand and the food industry and the governments on the other hand.

As indicated, there is thus evidence to suggest that trust is a valuable strategic variable for marketers in the food industry to consider when consumers are concerned about the safety and quality of processed food products. But is it possible to put forward guidelines to direct marketers on how to install trust with the consumers?

\section{The Danish-British Bacon Supply Chain}

The Danish-British bacon supply chain is an appropriate contextual setting for investigating how, if at all, marketers have installed trust with the consumers. Total Danish agricultural exports are valued at more than eight billion British pounds annually; this equates to over 30 per cent of the country's total export earnings. At some two billion British pounds, pig meat products are among the most important exports; about 80 per cent of the products are exported with two-thirds going to EU countries. In terms of value, 20 per cent of the pig meat product exports and 90 per cent of the bacon product exports are for the British market. The value of the bacon product exports to the British market alone is 250 million British pounds annually (Danske Slagterier 1998).

In the 1990s, Denmark's historically strong position on the British market was challenged, however, a development that caused much concern in Denmark, which has only few natural resources other than farming. One serious challenge was that British consumers wanted to be assured that the bacon supply chain was designed to deliver safe and high quality products and 
that the farming systems were environmentally friendly and conformed to animal welfare (Meat and Livestock Commission 1997; Woolven 1996). Another serious challenge was that British legislation in 1999 banned stall-and-tether pig production, which made it difficult, if not impossible, for processors and retailers in Britain to import Danish bacon products that for the majority originated from such traditional productions (Vestjyske Slagterier 1997). Although the legislation only applies to pig production in Britain, it was argued that the same restriction should be imposed on pig farmers in Denmark who otherwise could sell at lower prices since they would not need to invest in new production systems. In 1999, well in excess of 80 per cent of the British pig meat production complied with the new legislation but no more than about 15 per cent of the Danish pig meat production did that (Andersen 1998).

Only lately has the Danish bacon sector appreciated the seriousness of the challenges. One of the more apparent responses has been that the sector is now changing to untethered pig production. In an effort to address consumer demands for animal welfare and product safety, the sector is also critically examining its practice of teeth-and-tail clipping and inclusion of meat and bone meal in rations (Meat and Livestock Commission 1997). Finally, in addition to frequent and effective communication campaigns, the sector has begun to provide consumers with assurances about production and processing methods by means of trust-based marketing activities, including the development of quality assurance schemes and food safety assurance schemes that seek to enhance the image of the sector (Sloyan 1998).

\section{RELATIONSHIP MARKETING}

The marketing environment and business organisations changed radically toward the end of the twentieth century. Markets became more global and technologically sophisticated; and 
with intense competition and demanding consumers, companies placed greater emphasis on service (e.g., Brodie 1999). Relationship marketing was now being advocated as the appropriate paradigm for all businesses (e.g., Christopher et al. 1991; Gordon 1998; Gummesson 1999). It was argued that traditional marketing with its 4Ps framework (price, product, place and promotion) is too simple for today's competitive environment, but that relationship marketing, in contrast, seeks to improve business performance by means of relationships, networks and interactions. But how do companies build relationships with their important markets?

Young and Wilkinson (1989) have noted that the marketing literature historically has examined relationships in terms of power, conflict, opportunistic behaviour and control (e.g., Gaski 1984; Spekman and Sawhney 1990; Stern and El-Ansary 1992). The introduction of relationship marketing has, however, produced a more harmonious view of relationships with constructs of concern, commitment, service, promises - and trust, which is the focal point for this article (e.g., Anderson and Weitz 1992; Dwyer et al. 1987; Ganesan 1994).

\section{Trust}

Many authors have attempted to define trust (Anderson and Narus 1990; Bagozzi 1974; Ganesan 1994; Geyskens and Steenkamp 1995; Gulati 1995; Moorman et al. 1992; Ring and Van de Ven 1994; Shapiro 1987). Generally speaking, trust has been defined as the "willingness to rely on an exchange partner in whom one has confidence" (Lewin and Johnston 1997: 28; see also Deutsch 1960; Mayer et al. 1995; Moorman et al. 1992). In other words, a partner, who trusts another partner, has confidence in that partner (i.e., benevolence trust) and relies on that partner as an exchange partner (i.e., credibility trust). Trust is seen as 
central to successful relationships leading to higher levels of loyalty to the bargaining partner and thus to increased profitability because trust encourages partners to co-operate, seek longterm benefits and refrain from opportunistic behaviour (Anderson and Narus 1990; Anderson and Weitz 1992; Geyskens and Steenkamp 1995; Morgan and Hunt 1994). Honesty, safety, credibility and previous experience are among several dimensions of trust (Egan and Greenley 1998).

Trust has been investigated in domestic buyer-seller relationships (e.g., Lewin and Johnston 1997; Morgan and Hunt 1994) and international buyer-seller relationships (e.g., Freytag and Nielsen 1990; Patterson et al. 1998). Some studies have argued that trust emerges from factors specific to the buyer-seller interaction (Sako 1992) but, recently, Johnson and Grayson (1999) proposed four types of trust some of which emerge from non-specific buyer-seller interaction factors. These types of trust are as follows.

Generalised trust Generalised trust is dictated by general shared norms of behaviour and enforced by social mechanisms, such as peer pressure and threat of ostracism. People operate under an assumption of generalised trust until they are given reason to do otherwise, and so greater generalised trust fosters willingness to do business together.

System trust

System trust is written down in rules and controlled by legislative and regulatory institutions, such as trade commissions and health departments. People base their trust upon these written rules and how effective the legislative and regulatory institutions are in enforcing the rules. 

between two partners and thus depends on the behaviour of each partner and the history of interactions among the partners. It appears that trust is built through 'spiral re-enforcement'. That is, process-based trust moves from being fragile to being resilient.

Personality-based trust Personality-based trust is determined by individuals' personality traits and tells how willing an individual is to trust a partner. This type of trust is especially important in the initial stage of a relationship when circumstances are ambiguous and specific interaction-based clues are not available.

Johnson and Grayson provided no empirical evidence to support their proposal, though, but if trust indeed is paramount to successful relationships and thus a valuable strategic variable, marketers should appreciate that there may be different types of trust when they examine the influence of trust on their business. In this regard it is important to understand that trust is a process that changes over time and that it thus may be initiated and enhanced by the marketer (Phan et al. 1999). But what happens when buyers question the intentions and motives of the suppliers and/or ask whether the suppliers can perform reliably?

The present study seeks to test three propositions:

- There are different types of trust.

- Each type of trust is a valuable strategic variable.

- When one type of trust is not available it is possible and necessary to draw on other types. 


\section{RESEARCH METHODOLOGY}

The case research method was the most appropriate method for collecting empirical evidence and addressing the propositions. First, the objective of the study was to explore and gather detailed evidence of how, if at all, different types of trust have been implemented. Since the phenomenon of implementing trust was contemporary and on going, the activities had to be investigated within their real-life context. The case research method facilitates the exploration of complex social processes by taking a holistic perspective on real-life events with all of their potentially rich and meaningful characteristics intact. Second, there was little prospect of simplifying matters by excluding some variables whilst controlling and manipulating others. The case research method, however, avoids the need to pre-select the context type variables to be included in the investigations; instead, the important contextual variables impinging on the behaviour of interest are observed, over time. The case research method also does not suffer from the limitations of relativism because it reaches the external reality by collecting phenomena, such as interview respondents' perceptions. Throughout this process, findings are evaluated through consideration of reliability and validity, as illustrated in Table I (Yin 1994).

\section{Table 1. Reliability and validity of case research data}

Reliability of the data was increased through the development of clearly conceptualised constructs (i.e., the four types of trust) and the use of multiple indicators. Overall, the in-depth interviews were conducted and analysed by the author using a specific coding scheme who then passed it on to a colleague who carried out an independent analysis using the same coding scheme. The two sets of analysis were then compared for goodness-of-fit and disparities were reconciled through a third data interpreter.

Construct validity was secured with the use of multiple sources of evidence, such as in-depth interviews, company newsletters, annual reports and records of suppliers and customers. Interview respondents were invited to review drafts of case study reports.

Content validity was pursued by first asking interview respondents what they understand by the term 'relationship marketing' before probing to determine which activities they see as part of relationship marketing. These procedures were used to bridge any confusion between definition and measures.

Interpretive validity was accomplished by approaching interview respondents for a second, or even third, interview when points raised in an interview had been ambiguous. Respondents were also invited to review the draft for the case study report.

Contextual validity was sought by tape-recording the interviews for later transcription.

External validity was sharpened with the specification of the particular population of interest, that is Danish suppliers and processors of bacon products to the British market. 


\section{Design of the Case Research Study}

The study, which this article reports on, was a multiple case study. It involved a number of suppliers, processors and retailers in the Danish-British bacon supply chain. The primary unit of analysis, which defines the design of the case study, was the individual supplier, processor and retailer; and the sub-units were the marketing philosophy and the trust-installing activities of these individuals.

\section{Development of Theory from Case Research Data}

Theory from the case research data was developed by means of a procedure consisting of eight steps (Eisenhardt 1989). Cases were chosen for theoretical reasons. The study included Danish Crown and Vestjyske Slagterier that together have 80 per cent of the market for Danish pig meat products; three other entities were included in the study:

- Tulip International that is responsible for the marketing of bacon products from Danish Crown.

- The Federation of Danish Pig Producers and Slaughterhouses that co-ordinates the overall marketing of Danish bacon products.

- ESS-Food that distributes 20 per cent of all pig meat products from Denmark.

The study involved interviews with both sides of a relationship (dyadic approach); this approach has been regarded as necessary to fully understand a relationship (e.g., Anderson 1994). Although different sources provided information for the cases, the in-depth interview was the main source of information, which is in accordance with Perry (1998). The data was qualitative in nature; such data accommodate the local groundedness of the phenomena under 
investigation. The author interviewed the respondents in multiple-hour sessions; interviews were tape-recorded in order to ensure reliability and later transcribed to allow analysis.

Overall, the study gathered data of two types: the basic characteristics of the organisations and a thorough portrait of their trust-installing activities. The analysis of interview data was carried out in two stages: within-case analysis involving write-ups for each case and crosscase analysis involving searches for cross-case patterns. Each case was analysed in the fourstage interactive process proposed by Miles and Huberman (1994). This process involved coding, memoing about codes and different types of trust and testing propositions. Interpretations were backed up through triangulation: if possible, any claim was supported with multiple evidence (Yin 1994).

\section{FINDINGS}

The challenges faced by the Danish bacon sector were first assessed using Porter's (1985) model of five distinct competitive forces. This assessment was based upon not only the findings from the multiple case study but also studies from the literature. Overall, the following was found:

- Suppliers prefer to supply the market with bacon products at guaranteed prices.

- Processors want to do business with preferred suppliers and retailers.

- Retailers want timely deliveries of high quality, consistent bacon products at low prices from preferred processors.

- Consumers expect that bacon products are safe and of high quality; that the products do not vary between purchases; and that farming methods are environmentally friendly and conform to animal welfare. 
The latter finding (i.e., that consumers expect that bacon products are safe and of high quality etc.) is of particular interest: these expectations necessitate that trust-based marketing activities be installed, as we shall see shortly.

Having assessed the Danish bacon sector, the case study then proceeded to test the propositions. Overall, the study found evidence to support that trust is an important construct of the marketing philosophy; there was also evidence to suggest that trust-installing activities result in increased profitability for the bacon supply chain (see also, for example, Nielsen 2000). Thus, the case study found that some companies are more successful than others because the degree of trust between the company and its business partners is high. (Case interview evidence has been listed in Table II, which is found toward the end of this section. Evidence has also been included for business-to-business activities although the article mostly focuses on trust-based activities toward the consumers.) As one British executive manager explained:

"If [a processor or retailer] has bought 20 tonnes of meat product and is waiting for those products then it creates huge problems if the delivery is late or wrong. This is why trust is very important."

Means of installing trust in a business partner include timely deliveries that conform to specifications; general reliability; know-how of production requirements; valuable information about the market; capable employees; appropriate service; and fair prices.

The study found evidence that there are different types of trust and that, when one type of trust is not available, it is necessary and possible to draw on other types. When the British government thus failed to protect its citizens from BSE infected meat products, retailers in the 
Danish-British bacon supply chain realised that they could no longer rely on the government to foster comfort with food safety and quality (Wilson and Clarke 1998). As one British executive marketing director said:

\begin{abstract}
"People ... are having an enormous amount of trust in the retailer's label, and trust in [the private labels from] Tesco or Sainsbury's is a very important thing because they [the private labels] will rank higher in a lot of instances than major brands or manufacturers and certainly higher than a lot of institutions or governments. So people ... probably trust Tesco more than they would trust the Church of England or certainly more than they would trust the government and so on."
\end{abstract}

Consumers want to trust the suppliers, processors and retailers in the bacon supply chain to carefully monitor the production of bacon products and to control potential hazards. If necessary, players in the bacon supply chain should respond appropriately to accidents according to legislative requirements and consumer requirements. The retailers, therefore, turned from one system trust (i.e., the British legislation) to another system trust installing their own meat assurance schemes. The retailers did this because of two reasons. First, it was believed that there is greater food product safety and quality with such assurance schemes, as problems can more quickly be identified. Second, the diligence with which the retailers, and their suppliers, operate can be communicated to the consumer - and communication was believed to foster trust resulting in the consumers continuous buying the bacon products.

In Denmark, a meat quality assurance scheme has now been launched and some ten per cent of the national pig production have qualified (Boesen 1998; Lindhardt 1998). This scheme, the Danish Quality Guarantee, applies to the whole of the pig meat sector and covers all Danish pig meat products exported to the British market. The integrated structure of Denmark's meat sector is known as the Integrated Production System (Figure 1). 


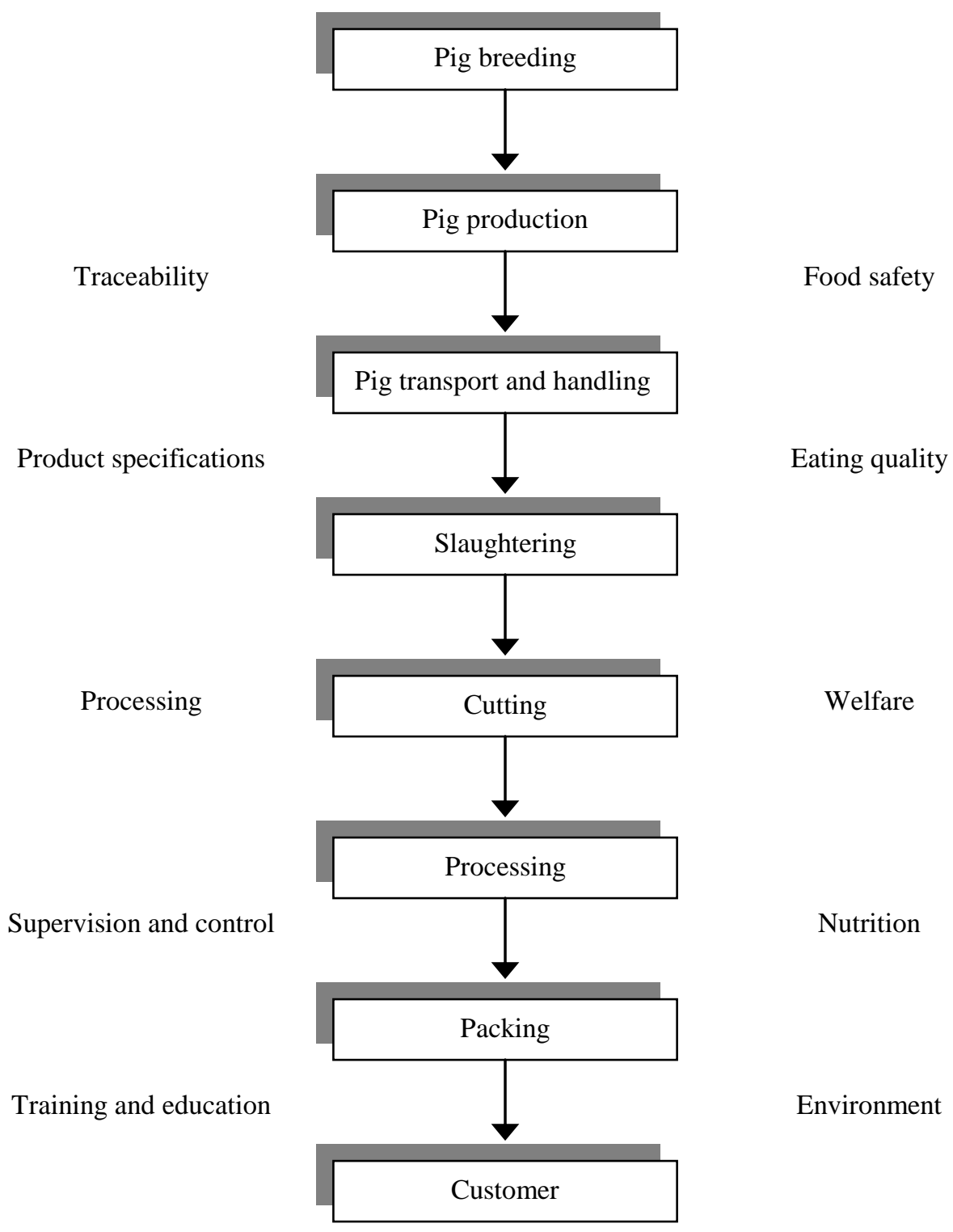

\section{Figure 1. Integrated Production System}

Source: Danske Slagterier (1999), The Danish Pigmeat Industry, Copenhagen.

As illustrated in the figure, the Integrated Production System is a baseline for quality systems and quality parameters. Consider first the quality system. All farms have a unique herd number that makes it possible at the slaughterhouse to trace back an animal to the particular pig breeder. Product specifications are prepared for pig meat products sold in Britain while processing is being carried out according to consumer requirements as well as legislation. The two steps of processing and packaging is being supervised and controlled by the industry and 
governmental veterinary services. Training and education refer to the fact that farm managers and employees at slaughterhouses undergo formal study programmes.

Consider next the quality parameters. Food safety is concerned with enforcing industry-wide standards to quality control. Furthermore, and in a response to the consumers, the industry in Denmark has installed a ten-point plan that places strong emphasis on eating quality. The industry has also found it important to examine issues of welfare, nutrition and environment in order to meet the growing demand of pig meat from farming methods that are environmentally friendly and conform to animal welfare. Overall, the described two-tier system offers a number of benefits including the following ones:

- Excellent standards of meat safety, meat quality, and animal welfare are developed.

- Best practice is shared throughout the pig meat sector.

- The latest research and development are disseminated to everyone.

The evidence from the case study also showed that process-based trust may replace system trust as a valuable strategic variable. By means of campaigns, British consumers long pressed for improved animal welfare so that the British government eventually turned these requirements into legislation. In an effort to comply with British consumers' demand for animal welfare, Danish farmers have not only changed to untethered production systems but are also looking into their practice of teeth-and-tail clipping and the inclusion of meat and bone meal in rations. The result has been that when British consumers felt that Danish farmers could be relied upon they continued to buy the Danish bacon products. 
Tulip International had recently installed a relationship marketing programme that is built around trust (in general). The programme went through three phases:

The first phase Advertising was employed as the route of brand advertising to a mass market. The company put emphasis on specific brand benefits although its bacon products still were a complimentary offer to the retailers' private label products. Regular consumers were rewarded for their loyalty with on-pack offers. The first phase was centred on transaction marketing. As the marketing director explained:

\footnotetext{
"[When] we look at our more classic marketing route for our ... brand we are of course trying to attract own label users to the brand so in that sense our more classic route is trying to attract new users... I personally see advertising as being the more typically route of a brand advertising to a mass market and not really having that direct dialogue with the end customer."
}

The second phase The company sought to establish a direct dialogue with the consumers. It achieved this by putting in place a so-called care-line on the packages of bacon products: a statement from the production manager, together with a telephone number, was listed and consumers were invited call in with any comments or inquiries; the consumers who did so were rewarded. At the same time, the company built up a database of known bacon purchasers. The second phase was centred on process-based trust. As the marketing director said:

\footnotetext{
"Trust is important... trust combined with service and understanding [of the customer's needs]."
} 
The third phase Relationships between the company and the consumers got closer. There were competitions, running over three-week periods, in radio and magazines. In the retailer stores there were free samples of bacon products; point-of-sale materials such as recipes offered inspiration for the consumers. The third phase was centred on personality-based trust. As the marketing director described:

\footnotetext{
"There is also the routes of radio and magazine competitions. There is an element of talking direct to the consumer or - be it that again it is on a very limited basis - on a competition-type basis."
}

In future phases, Tulip International plans to enter into direct mail to some of the consumers. Overall, the programme shows that the company moved from addressing the concerns of the mass market (advertising) to addressing the concerns of the individual consumer (care-line and direct mail).

As earlier mentioned, in addition to the text units already referred in the main text, Table II provides an overview of representative text units that support the claims that have been made throughout this article. 
Table 2. Case interview evidence of different sources of trust

\begin{tabular}{|c|c|c|}
\hline System trust & Process-based trust & Personality-based trust \\
\hline $\begin{array}{l}\text { "People ... are having an enormous } \\
\text { amount of trust in the retailer's label, } \\
\text { and trust in [the private labels from] } \\
\text { Tesco or Sainsbury's is a very } \\
\text { important thing because they [the } \\
\text { private labels] will rank higher in a lot } \\
\text { of instances than major brands or } \\
\text { manufacturers and certainly higher } \\
\text { than a lot of institutions or } \\
\text { governments. So people ... probably } \\
\text { trust Tesco more than they would trust } \\
\text { the Church of England or certainly } \\
\text { more than they would trust the } \\
\text { government and so on." } \\
\text { "[When] we look at our more classic } \\
\text { marketing route for our... brand we are } \\
\text { of course trying to attract own label } \\
\text { users to the brand so in that sense our } \\
\text { more classic route is trying to attract } \\
\text { new users... I personally see } \\
\text { advertising as being the more typically } \\
\text { route of a brand advertising to a mass } \\
\text { market and not really having that } \\
\text { direct dialogue with the end customer." }\end{array}$ & $\begin{array}{l}\text { "Trust is built between [a firm and a } \\
\text { customer] when they do business } \\
\text { together week after week, month after } \\
\text { month, year after year." } \\
\text { "If [a processor or retailer] has bought } \\
\text { twenty tonnes of meat product and is } \\
\text { waiting for those products then it } \\
\text { creates huge problems if the delivery is } \\
\text { late or wrong. This is why trust is very } \\
\text { important." } \\
\text { "Trust is important... trust combined } \\
\text { with service and understanding [of the } \\
\text { customer's needs]." } \\
\text { "Hopefully, the relationship between } \\
\text { the company and the customer is the } \\
\text { stronger relationship... [Whatever the } \\
\text { trader has delivered] has been through } \\
\text { the company... image... good service, } \\
\text { reasonable prices, reliability... } \\
\text { information flow." }\end{array}$ & $\begin{array}{l}\text { "Relationship is how you sit and talk } \\
\text { with your customer, the right spirit of a } \\
\text { conversation, being close to the } \\
\text { customer - perhaps not friends but } \\
\text { definitely close to the customer... so } \\
\text { that the buying experience is pleasant." } \\
\text { "Relationships is built by inviting your } \\
\text { customer out for dinner, playing golf } \\
\text { with them... everything that binds } \\
\text { people together." } \\
\text { "Why should he make business with } \\
\text { us? Simply because he has a good } \\
\text { relationship with us... So even though } \\
\text { a competitor has a good product he } \\
\text { still wants to do business with us... } \\
\text { Sometimes we may not get exclusivity } \\
\text { but only access to doing business with } \\
\text { a customer." } \\
\text { "There is also the routes of radio and } \\
\text { magazine competitions. There is an } \\
\text { element of talking direct to the } \\
\text { consumer or - be it that again it is on a } \\
\text { very limited basis - on a competition- } \\
\text { type basis." } \\
\text { "[If this particular employee is leaving } \\
\text { the firm] then because of the } \\
\text { relationship [between this employee } \\
\text { and the customer] we as a firm might } \\
\text { suffer.' }\end{array}$ \\
\hline
\end{tabular}

\section{THEORETICAL AND MANAGERIAL IMPLICATIONS AND}

\section{DIRECTIONS FOR FUTURE RESEARCH}

The objective of the qualitative multiple case study was to test three propositions: (1) that there are different types of trust, (2) that each type of trust is a valuable strategic variable and

(3) that when one type of trust is not available it is possible and necessary to draw on other types.

Overall, the case study found empirical evidence that trust is an important construct in relationship marketing. For example, with many consumers having little faith in the food 
industry or in the governments, players in the Danish bacon sector found it necessary to implement trust-based marketing activities, most notably the Integrated Production System that serves as a baseline for quality systems and quality parameters. The bacon players have also invested in their relationships, networks and interactions with important markets; for example, Tulip International has moved from mass marketing to one-to-one marketing centred on personality-based trust.

Specifically, the study confirmed the propositions that there are different types of trust (generalised trust, system trust, process-based trust and personality-based trust) and that each type of trust is a valuable strategic variable. The study also found evidence to support the proposition that when one type of trust is not available it is possible and necessary to draw on other types. Danish bacon producers thus turned to their own system trust by installing meat assurance schemes instead of relying on the British government; in a similar way, processors and retailers in Britain first turned to their own system trust and then later switched to processbased trust by putting in place customer care-lines. By doing so, the players re-installed trustworthiness, and the Danish bacon export worth 250 million British pounds annually was safeguarded.

The managerial implications of the empirical findings are significant. In addition to more traditional marketing activities, marketers must undertake a number of other equally important tasks including the following ones:

- To promote the image of the company.

- To educate the consumers.

- To build relationships, networks and interactions with different markets. 
Consider first the promotion of the image of the company, which can take place through multiple channels. Tulip International thus uses advertisements on television, radio and magazines as well as point-of-sale materials - and has recently started to seriously explore routes of care-lines and direct mailing campaigns.

Then look at the education of the consumers. For example, British retailers have turned to their own system trust by means of meat assurance schemes and, in doing so, are addressing both the benefits of eating meat products from farms that have qualified to participate in the scheme (e.g., high nutritional value) and the risks (e.g., insignificant risk of contracting Creutzfeldt-Jakob disease when eating meat-assured products). It should be realised that the education of the consumers also can be undertaken by other players - for example, pig breeders, distributors and people who are working in the health service. The message to the consumers must be objective and balanced, though, because otherwise the consumers will not believe in the message; this could be achieved by employing credible sources, such as independent researchers/research agencies. And the communication channel through which the message travels must also allow the consumers to ask questions.

Finally examine the building of relationships, networks and interactions with different markets. It was evident from the case study that such ones have indeed been formed throughout the bacon sector one reason being that the meat assurance schemes require the cooperation of all players in the supply chain, including the pig breeders, the distributors, the slaughterhouses, the processors, the retailers and the controllers (as depicted in Figure 1).

One avenue for future research is the following one: In order to be effective, meat assurance schemes must be integrated along the whole bacon supply chain and that necessitates trust 
between the different players. But when a retailer works with many suppliers, confidential information from an inspection at one supplier's site might incidentally be passed on to another supplier. What are the circumstances, then, that foster enough trust between the players that these are able to put common goals above individual goals?

Another avenue is as follows: It is important for marketers to know if consumers believe in system trust because if this is the case other companies may then free-ride on the consumers' confidence without developing their own process-based trust with their consumers and thus save considerable amounts of money.

Yet a third avenue for future research is to examine whether or not there is a link between the trust that consumers place in a company and on the company's relative brand image. In general, successful brands tend to be those that are able to communicate core values that match those held by prospective consumers. For example, do consumers with greater trust in a company perceive it as different from those consumers who have a lower trust in the company? Finally, how does a company build a brand that fosters trust?

\section{REFERENCES}

American Agent \& Broker (1999), "Hartford expands food recall coverage", American Agent \& Broker, Vol. 71, No. 1, p. 63.

Andersen, F. (1998), "Britiske kvalitetsordninger", ds nyt, No. 1, pp. 10-11.

Anderson, E. and Weitz, B. (1992), "The use of pledges to build and sustain commitment in distribution channels", Journal of Marketing Research, Vol. 29, No. 1, pp. 18-34.

Anderson, J. C. and Narus, J. A. (1990), “A model of distributor firm and manufacturing firm working partnership", Journal of Marketing, Vol. 54, No. 1, pp. 42-58.

Anderson, W. T. (1994), "Deciphering dyads: concepts, methods, and controversies in relational research", Psychology \& Marketing, Vol. 11, No. 5, pp. 447-466.

Bagozzi, R. (1974), “What is a marketing relationship?” Der Markt, Vol. 51, pp. 64-69. 
Baines, R. N. and Davies, W. P. (1998), "Quality assurance in international food supply", in Ziggers, G. W., Trienekens, J. H. and Zuurbier, P. J. P. (Eds.), Proceedings of the 3rd International Conference on Chain Management in Agribusiness and the Food Industry, Wageningen Agricultural University, Wageningen, pp. 213-223.

Berry, D. G. (1998), "Surviving a product recall”, Dairy Foods, Vol. 99, No. 9, pp. 9.

Berry, L. L. (1983), "Relationship marketing", in Berry, L. L., Shostack, G. L. and Upah, G. D. (Eds.), Emerging Perspectives on Services Marketing, American Marketing Association, Chicago, Illinois, pp. 25-28.

Boesen, U. (1998), “Lup på kvaliteten”, Morgenavisen Jyllands-Posten, 1 October, p. 3.

Brodie, R. J. (1999), "Editorial: introduction to the special issue", Australasian Marketing Journal, Vol. 7, No. 1, pp. 1-3.

Buus, C. H. (1999), “Gen-firmaet i orkanens øje”, Ingeniøren, 16 April, 1st section, pp. 10-11.

Christopher, M., Payne, A. and Ballantyne, D. (1991), Relationship Marketing: Bringing quality, customer service, and marketing together, Butterworth-Heinemann, Oxford.

Collins, B. E. (1999), "Pairing relationship value and marketing", Australasian Marketing Journal, forthcoming.

Danske Slagterier (1998), Statistics 1997, Copenhagen.

Danske Slagterier (1999), The Danish Pigmeat Industry, Copenhagen.

Deutsch, M. (1960), "The effect of motivational orientation upon trust and suspicion", Human Relations, Vol. 13, pp. 123-140.

Dulen, J. (1999), "Changes proposed for food recalls", Restaurants \& Institutions, Vol. 109, No. 15 , p. 68.

Dwyer, F. R., Schurr, P. H. and Oh, S. (1987), "Developing buyer-seller relationships", Journal of Marketing, Vol. 51, No. 2, pp. 11-27.

Egan, C. and Greenley, G. (1998), "Evaluating stakeholder principles in strategic marketing management", in Egan, C. and Thomas, M. J. (1998), The CIM Handbook of Strategic Marketing: A practical guide for designing and implementing effective marketing strategies, Butterworth-Heinemann, Oxford, pp. 209-227.

Eisenhardt, K. M. (1989), "Building theories from case study research" Academy of Management Review, Vol. 14, No. 4, pp. 532-550.

Freytag, P. V. and Nielsen, O. (1990), "The buying behaviour in the furniture industry - a case study”, Marketing: Polish-Danish Perspectives, Folia Oeconomica 105, Acta Universitatis Lodziensis, Lodz University, Lodz, pp. 147-175.

Ganesan, S. (1994), "Determinants of long-term orientation in buyer-seller relationships", Journal of Marketing, Vol. 58, No. 2, pp. 1-19.

Gaski, J. F. (1984), "The theory of power and conflict in channels of distribution", Journal of Marketing, Vol. 48, No. 3, pp. 9-29.

Geyskens, I. and Steenkamp, J.-B. (1995), "An investigation into the joint effects of trust and interdependence on relationship commitment", in Bergadaà, M. (Ed.), Proceedings of the 24th Annual Conference of the European Marketing Academy, École Supérieure des Sciences Économiques et Commerciales, Cergy-Pontoise, pp. 351-371.

Goddard, S. (1999), "Illnesses spur Coke recall”, Business Insurance, Vol. 33, No. 25, pp. 2527.

Gordon, I. (1998), Relationship Marketing: New strategies, techniques and technologies to win the customers you want and keep them forever, John Wiley \& Sons, Toronto.

Gulati, R. (1995), "Does familiarity breed trust? The implications of repeated ties for contractual choice in alliances", Academy of Management Journal, Vol. 38, No. 1, pp. 85112. 
Gummesson, E. (1999), Total Relationship Marketing: From the 4Ps - product, price, promotion, place - of traditional marketing management to the 30Rs - the thirty relationships - of the new marketing paradigm, Butterworth-Heinemann, Oxford.

Harker, M. J. (1999), "Relationship marketing defined? An examination of current relationship marketing definitions", Marketing Intelligence \& Planning, Vol. 17, No. 1, pp. 12-20.

Johnson, D. and Grayson, K. (1999), "Sources and dimensions of trust in service relationships", in T. A. Swartz and D. Iaccobucci (Eds.), Services Marketing and Management, Sage, Thousand Oaks, California, forthcoming.

Lewin, J. E. and Johnston, W. J. (1997), "Relationship marketing theory in practice: a case study", Journal of Business Research, Vol. 39, No. 1, pp. 23-31.

Licking, E. and Carey, J. (1999), "How to head off the next tainted-food disaster", Business Week, 1 March, p. 34.

Lindhardt, C. (1998), "Kvalitetskød mærkes", Politiken, 1 October, p. 16.

Mayer, R. C., Davis, J. H. and Schoorman, F. D. (1995), "An integrative model of organizational trust", Academy of Management Review, Vol. 20, No. 3, pp. 703-734.

Meat and Livestock Commission (1997), "Industry development", in Beef Yearbook 1997, Milton Keynes, pp. 10-23.

Miles, B. and Huberman, A. M. (1994), Qualitative Data Analysis: An expanded sourcebook, 2nd edition, Sage Publications, Thousand Oaks, California.

Moorman, C., Zaltman, G. and Deshpandé, R. (1992), "Relationships between providers and users of marketing research: the dynamics of trust within and between organizations", Journal of Marketing Research, Vol. 29, No. 3, pp. 314-329.

Morgan, R. M. and Hunt, S. D. (1994), "The commitment-trust theory of relationship marketing", Journal of Marketing, Vol. 58, No. 3, pp. 20-38.

Morgenavisen Jyllands-Posten (1998), "Risiko for antibiotika i frugt og grøntsager", Morgenavisen Jyllands-Posten: Indland, 1 October, p. 3.

Murray, I. (1999), "Cases of human 'mad cow' disease rise to 40", The Times, 16 April, p. 16.

Möller, K. and Halinen-Kaila, A. (1998), "Relationship marketing: its disciplinary roots and future directions", in Andersson, P. (Ed.), Proceedings of the 27th Annual Conference of the European Marketing Academy, Elanders Gotab, Stockholm, Vol. 1, pp. 289-310.

Nielsen, J. B. (2000), "Tillid sælger masser af mælk", Børsen, 19 December, p. 12.

Patterson, P., Styles, C. and Ahmed, F. (1998), "The determinants of successful relationships in international business", in Brodie, R., Brookes, R., Colgate, M., Collins, B. and Martin, A. (Eds.), 6th International Colloquium in Relationship Marketing, 7-8 December, The University of Auckland, Auckland, pp. 23-55.

Perry, C. (1998), "Processes of a case study methodology for postgraduate research in marketing", The European Journal of Marketing and The New Zealand Journal of Business, Vol. 32, No. 9/10, forthcoming.

Phan, M. C. T., Styles, C. W. and Patterson, P. G. (1999), "An empirical examination of the trust development process linking firm and personal characteristics in an international setting", working paper for 28th Annual Conference of the European Marketing Academy, 11-14 May, Humboldt-Universität zu Berlin, Berlin.

Politiken (1999a), "Okseblod i franske vine", www.politiken.dk.

Politiken (1999b), "Hård dansk kritik af belgisk fødevareskandale", www.politiken.dk.

Porter, M. E. (1985), Competitive Strategy: Techniques for analyzing industries and competitors, Free Press, New York.

Ratzan, S. C. (Ed.) (1998), The Mad Cow Crisis: Health and the Public Good, UCL Press, London. 
Ring, P. S. and Van de Ven, A. H. (1994), "Developmental processes of cooperative interorganizational relationships", Academy of Management Review, Vol. 19, No. 1, pp. 90-118.

Sako, M. (1992), Prices, Quality and Trust: Interfirm relations in Britain and Japan, Cambridge University Press, Cambridge.

Shapiro, S. P. (1987), "The social control of impersonal trust", American Journal of Sociology, Vol. 93, November, pp. 623-658.

Sloyan, M. (1998), "The strategy for pig meat", in Sloyan, M. (Ed.), Pig Yearbook 1998, Meat and Livestock Commission, Milton Keynes, pp. 2-4.

Snehota, I. and Söderlund, M. (1998), "Relationship marketing - what does it promise and what does it deliver? An empirical examination of repeat purchase customers", in Andersson, P. (Ed.), Proceedings of the 27th Annual Conference of the European Marketing Academy, Elanders Gotab, Stockholm, Vol. 1, pp. 311-330.

Spekman, R. E. and Sawhney, K. (1990), "Toward a conceptual understanding of the antecedents of strategic alliances", Report 90-114, Marketing Science Institute, Cambridge, Massachusetts.

Stern, L. W. and El-Ansary, A. (1992), Marketing Channels, 4th ed., Prentice-Hall, Englewood Cliffs, New Jersey.

Tansey, G. and Worsley, T. (1995), The Food System: A guide, Earthscan Publications, London

The Economist (1998a), "The science of BSE: bungled", The Economist, 14 March, pp. 2123.

The Economist (1998b), "The science of BSE: birth of a disaster", The Economist, 14 March, p. 22.

The Economist (1999a), "Belgium's rotten food”, The Economist, 5 June, pp. 54.

The Economist (1999b), "Genetically modified food", The Economist, 19 June, pp. 21-23.

Vestjyske Slagterier (1997), Beretning \& Regnskab 1996/97.

Wilson, T. P. and Clarke, W. R. (1998), "Food safety and traceability in the agricultural supply chain using the internet to deliver traceability", in Ziggers, G. W., Trienekens, J. H. and Zuurbier, P. J. P. (Eds.), Proceedings of the 3rd International Conference on Chain Management in Agribusiness and the Food Industry, Wageningen Agricultural University, Wageningen, pp. 667-675.

Woolven, J. (1996), Food Industry Forces of Change, IGD Business Publications, Watford.

Yin, R. K. (1994), Case Study Research: Design and methods, 2nd edition, Sage, Thousand Oaks, California.

Young, L. C. and Wilkinson, I. F. (1989), "The role of trust and cooperation in marketing channels: a preliminary study", European Journal of Marketing, Vol. 23, No. 2, pp. 109122. 